\title{
石川県における農村地域住民の成人病の疫学 健康診断受診後の死亡状況
}

\author{
中川秀 昭, 河 野 俊一, 奥 村義治, 辻川研一郎 ${ }^{*}$ \\ 金森ちえ子, 鏡 森 定 信 $^{2 *}$
}

近年の農村地域住民の成人病罹患状況を把握し, 成人病に対する Risk Factor 算出する為の手 始めとして，昭和 46 年から53年までの 8 年間に石川県農業協同組合連合会と協力して，地域農業協 同組合および支所を単位として行なった成人病総合健康診断受診者 28643 人(男 6872 人, 女 21771 人) の昭和 55 年末むで追跡調査を実施し, 死亡原因の検討を行なった。一人平均観察人年は 5.8 人年であ る。

観察期間内の死亡者は 876 人で調査対象者の $3.1 \%$ 占め, 男の死亡割合は女の 3 倍に達している。 初診時年令階級別死亡割合は男女とも年令が高くなるにつれて増加しており，29才以下を除いて女 より男の死亡割合が有意に高率であった。

死因別死亡構成割合は循環器疾患が $22.0 \%$, 悪性新生物 $31.9 \%$, その他 $26.1 \%$ となっており, 男 では循環器疾患死亡が多く, 女では悪性新生物死亡が多い傾向がみられた。

観察期間内の 1,000 人年当りの死亡率は 5.2 (男 11.8 , 女 3.3 ) であり, 主要死因群別では悪性新生 物 1,000 人年対 1.7 (男 3.1 , 女 1.2 ) 脳卒中同 1.2 (男 2.8 , 女 0.7 ), 心疾患同 0.9 (男 2.3 , 女 0.5 ),

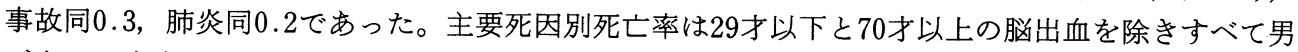
が女より高率であった。

\section{(1)農村住民 (2)死亡率 (3)成人病 (4)追跡調査 (5)健康診断}

\section{1.はじめに}

わが国では, 人口の高令化と死因構造の変化により, かつて国民病といわれた結核や急性伝染病などの感染 症による死亡が激減し，かわって悪性新生物，脳血管 疾患, 心臟病などのいわゆる成人病や糖尿病, 肝硬変 などによる死亡が死因の上位を占めるに至った。

現在, 総死亡に占める成人病死亡の割合は $70 \%$ に達 し, 今後さらに人口の高令化が進むにしたがって, こ の比率は一層大きくなるものと推定され, 成人病予防 対策はますます重要な課題となると考兄られる。

有効な成人病予防対策の確立のためには各成人病に 対するリスクファクターの把握が必須であり，このた め, 各成人病のリスクファクターに関する研究は広く 各地で行なわれて扣り, 循環器疾患と食塩摂取や血清

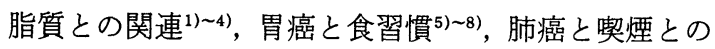
関連9 ${ }^{911)}$ など多くの成果が明らかにされている。

* 金沢医科大学公衆衛生学教室

$2 *$ 富山医科薬科大学医学部保健医学教室 （受付：昭和60年 1 月 14 日）
われわれは，昭和 46 年より現在まで，石川県共済農 業協同組合連合会と協力して，地域農業協同組合およ び支所を単位として成人病総合健康診断を行なって来 ている。健診項目は問診 (職歴, 家族歴, 既往歴, 食 習慣, 生活習慣, 自覚症状など), 身体計測, 血圧, 尿 検査 (蛋白, 糖, ウロビリノーゲン, 潜血), 心電困, 眼底, 血液検査 (随時血糖, コレステロール, 血清蛋 白, 尿素窒素, 黄疸単位, GOT, GPT, ZTT, TTT, $\mathrm{Al}-\mathrm{P}$ など)および胃部 X 線検査などである。昭和46年 から 57 年までに石川県内延 664 地区, 延 50,160 人（男 12,322 人，女 37,838 人）が受診した。

われわれはこれらの資料を用いて，各種成人病に対 するリスクファクターの算出を計画して拉り，その手 はじめとして, 今回, 昭和 46 年の総合健康診断開始よ り昭和53年までの 8 年間の受診者について，その転帰 の追跡調査を行ない, 成人病死亡の実態を明らかにす ることとした。

\section{2. 調查対象および方法}

昭和 46 年から昭和 53 年までの 8 年間に成人病総合健 康診断を受診した者を調查対象とした。受診者は 8 市 
27 町村の 199 単位農協掞上び支所で, 延 36,008 人（男 8,162 人，女 27,846 人)に達しており，これは一部山村 過疎地域を除いた石川県全域をカバーしている。

これらの対象者の 8 年間の受診票をレコードリン ケージし, 受診実人員を把握するとともに, 単位農協 の協力を得て, 受診後, 昭和 55 年末までの死亡, 転出 等に関する追跡調査を行ない, 死亡者については, 行 政管理庁の承認を得て（昭和56年12月22日，行管承統 第 459 号)人口動態統計死亡小票を用いて, 死因招よび 死亡年月日の確認を行なった。

これらの資料を基に, 受診者の初診時年令別に人年 法により観察人年を求め, 死因別死亡率を求めた。

\section{3. 調 査 成 績}

1) レコードリンケージと追跡調査

昭和 46 年から昭和 53 年の 8 年間に成人病総合健康診 断を受診した延 36,008 人の健診票をレコードリンケー ジさせた結果, 実受診人員は 28,643 人であり, 性別の 内訳は表 1 に示したと抒りである。

これを対象として, 昭和 $56,57,58$ の 3 年間にわたっ て追跡調查を実施したところ, 昭和 46 年から昭和 55 年 末までの 9 年間の死亡者は 876 人 ( $3.1 \%)$, 転出者は 136 人（男 21 人，女 115 人）であった。

初診年度から昭和 55 年末までの総観察人年は

表 1 . 農協検診追跡調査対象者

（昭和 $46 \sim 55$ 年受診者, 昭和 55 年末現在)

\begin{tabular}{c|r|r|r}
\hline 区 分 & \multicolumn{1}{|c|}{ 男 } & \multicolumn{1}{c|}{ 女 } & \multicolumn{1}{c}{ 計 } \\
\hline 延 受 診 数 & 8,162 & 27,846 & 36,008 \\
実 受 診 数 & 6,872 & 21,771 & 28,643 \\
観 察 人 年 & 37,713 & 129,246 & 166,959 \\
1 人平均人年 & 5.49 & 5.94 & 5.83
\end{tabular}

表 2 . 死亡調査結果

(昭和 55 年末現在)

\begin{tabular}{|c|c|c|c|c|c|}
\hline & & \multicolumn{2}{|r|}{ 男 } & \\
\hline & & 受診数 & 死亡数 (\%) & 受診数 & 死亡数 (\%) \\
\hline \multirow[t]{3}{*}{ 公 } & 数 & 872 & $445 \quad(6.5)$ & 21,771 & $431 \quad(2.0)$ \\
\hline & 29歳以 & 354 & $0(-)$ & 927 & $2(0.2)$ \\
\hline & 30 39歳 & 954 & $8(0.8)$ & 4,246 & $12(0.3)$ \\
\hline \multirow{4}{*}{$\begin{array}{l}\text { 初診時 } \\
\text { 年齢別 }\end{array}$} & 40４9歳 & 1,897 & $44 \quad(2.3)$ & 7,048 & $61 \quad(0.9)$ \\
\hline & 50 59歳 & 1,814 & $92(5.1)$ & 6,082 & $120(2.0)$ \\
\hline & 60 69歳 & 1,553 & $196(12.6)$ & 3,102 & $175(5.6)$ \\
\hline & 70葴以上 & 301 & $105(34.9)$ & 330 & $61(18.5)$ \\
\hline
\end{tabular}

166,959 人年となり, 1 人平均観察人年は 5.8 人年であ り，性別の内訳は同じく表 1 に示したと拉りである。 死亡調査の結果は表 2 に示したと招りで, 男では受 診者 6,872 人のらち 445 人 $(6.5 \%)$ が死亡して打り, 女 では 21,771 人のうち431人 (2.0\%) が死亡していた。 これを初診時年令階級別にみると, 男女とも年令の上 昇とともに死亡割合が上昇して扔り，29才以下の年令 階級を除いて男の死亡割合が女の死亡割合より高く, その差は統計的に有意であった $(\mathrm{P}<0.05)$ 。

表 3 亿市郡別・地域別死亡状況を男女別に示した。 男女別に市郡別の死亡割合をみると，男女とも市部に くらべて郡部の死亡割合が高く, 男では統計的に有意 であった $(\mathrm{P}<0.05)$ が，女では有意差は認められな かった。また, 石川県を河北郡以南の加賀地方と, 羽 咋郡以北の能登地方に分けて死亡割合をみると, 男女 いずれも能登地方が高率であり, 男女ともその差は統 計的に有意であった $(\mathrm{P}<0.05)$ 。

2 ) 死因別死亡状況

死亡者 876 人の死因調査による主要死因別(原死因に よる）死亡数および死亡構成割合は表 4 に示したとお りである。

死亡構成割合が女より男で高い死因は, 脳梗塞, 虚 血性抒よび高血圧性心疾患, 食道癌, 気管, 気管支お よび肺の癌, リンパ括よび造血器の癌, 事故, 肺炎, その他の呼吸器疾患, 肝硬変であった。

性別, 初診時年令階級別に主な死因群別の死亡構成 割合をみると図 1 のと抢りで, 男の30才代では悪性新 生物（がん）が第 1 位で $37.5 \%$ を占め, 第 2 位は脳血 管疾患（脳卒中）之事故・自殺（外因死）がそれぞれ $25.0 \%$ である 40 才代では 1 位がん $34.1 \% ， 2$ 位外因 死 $27.3 \%, 3$ 位脳卒中 $18.2 \%$ であり，50才代は 1 位が ん $38.4 \%, 2$ 位脳卒中 $20.7 \%, 3$ 位心疾患 $16.3 \%$ であ る。60才代は 1 位脳卒中 $28.6 \% ， 2$ 位がん $21.4 \% ， 3$ 位心疾患 $20.9 \%$ であり, 70才以上では 1 位心疾患 $22.9 \%, 2$ 位がん $21.9 \%, 3$ 位脳卒中 $21.0 \%$ の順となっ

表 3 . 市郡別地域別死亡状況の比較

\begin{tabular}{|c|c|c|c|c|c|}
\hline \multirow{2}{*}{ 区 } & \multirow{2}{*}{ 分 } & \multicolumn{2}{|r|}{ 男 } & \multicolumn{2}{|r|}{ 女 } \\
\hline & & 受診数 & 死亡数 (\%) & 受診数 & 死亡数 (\%) \\
\hline 総 & 数 & 6,872 & $445 \quad(6.5)$ & 21,771 & $431 \quad(2.0)$ \\
\hline \multirow{2}{*}{ 市郡別 } & 市 部 & 3,478 & $205 \quad(5.9)$ & 11,248 & $207 \quad(1.8)$ \\
\hline & 郡 & 3,394 & $240 \quad(7.1)$ & 10,523 & $224 \quad(2.1)$ \\
\hline \multirow{2}{*}{ 地域別 } & 加賀地方 & 3,052 & $148 \quad(4.9)$ & 11,098 & $174(1.6)$ \\
\hline & 能登地方 & 3,820 & $297 \quad(7.8)$ & 10,673 & $257 \quad(2.4)$ \\
\hline
\end{tabular}


ていた。

女では，29才以下は，がんと外因死がそれぞれ 1 人 ずつであり，30才代ではその他の死因を除くと1位が ん $25.0 \% ， 2$ 位心疾患 $16.7 \% ， 3$ 位は脳卒中と外因死
がそれぞれ $8.3 \%$ であ。40才代では 1 位がん $47.5 \%$ ， 2 位外因死 $16.4 \% ， 3$ 位脳卒中 $14.8 \%$ であり，50才代 は 1 位がん $50.8 \%, 2$ 位脳卒中 $18.3 \%, 3$ 位外因死 $9.2 \%$ である。60才代は 1 位がん $31.4 \% ， 2$ 位脳卒中

表 4. 主要死因（原死因）別死亡数及び死亡構成比

(昭和 $46 \sim 55$ 年)

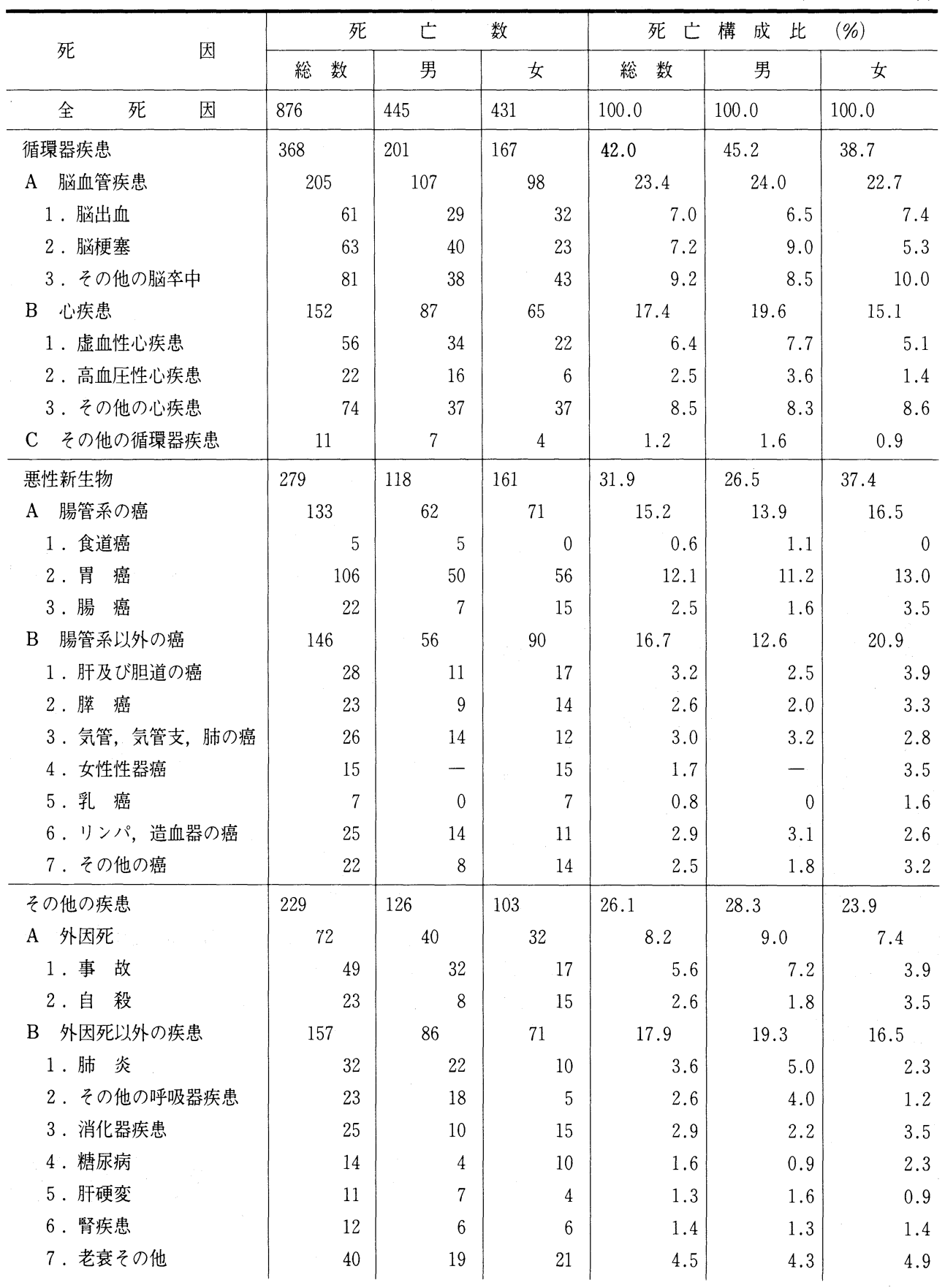


$25.7 \% ， 3$ 位心疾患 $18.3 \%$ であり，70才以上では 1 位 脳卒中 $34.4 \%, 2$ 位心疾患 $26.2 \% ， 3$ 位がん $19.7 \%$ の 順となっていた。

3 ) 初診時年令階級別死亡率

観察人年 1,000 人年あたりの死亡率をみると,全死因 では男11.8, 女 3.3 と男が約 3.5 倍高率である。初診時 年令階級別では 29 才以下では男 0 ,女 $0.4,30$ 才代では 男 1.5 ，女 $0.5 ， 40$ 才代では男 4.2 ，女 $1.3 ， 50$ 才代では 男9.3，女 $3.3 ， 60$ 才代では男 23.0 ，女 $9.8 ， 70$ 才以上で は男 62.8 , 女 32.0 と29才以下を除き，いずれも男の死 亡率が高くなっていた。

主要死因群別の初診時年令階級別 1,000 人年対死亡 率を図 2 に示した。脳卒中の死亡率は観察人年 1,000 人

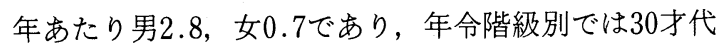
男 0.4 , 女 0,40 才代男 0.8 , 女 0.2 ，50才代男 1.9 , 女 0.6 , 60才代男 6.6 , 女 $2.5,70$ 才以上男 13.2 , 女 11.0 で あった。このらち脳出血の死亡率は 1,000 人年あたり男 0.8 , 女 0.2 であり, 脳梗塞は男 1.1 , 女 0.2 であった。


$\eta$, 年令階級別では 30 才代男 0.2 , 女 $0.1,40$ 才代男 0.6 ,

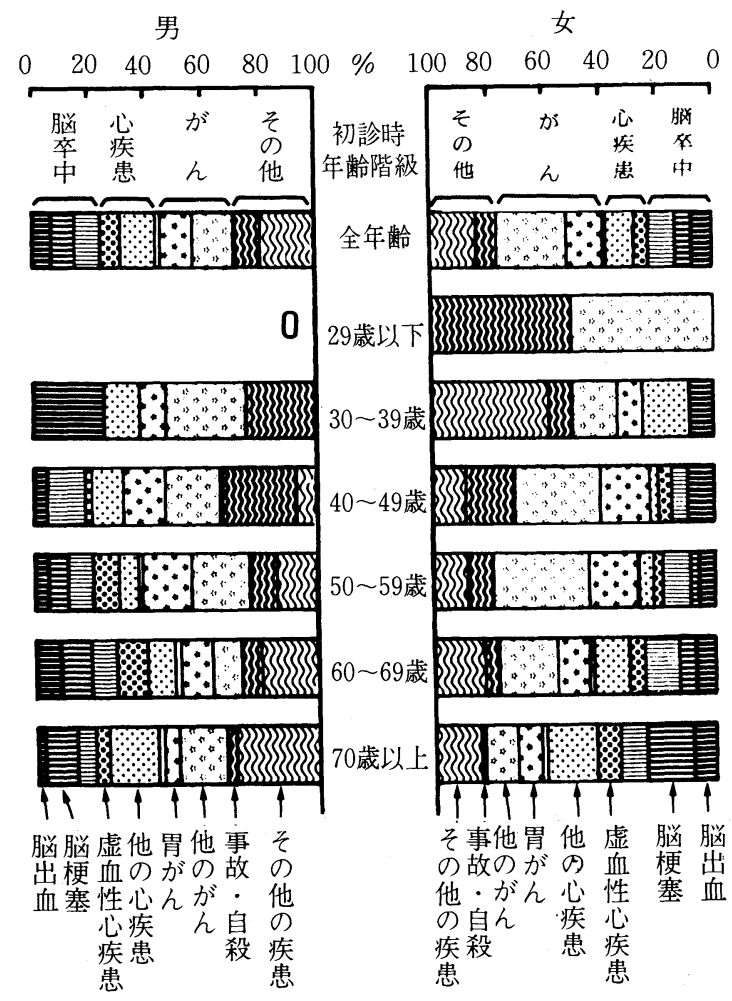

図 1. 初診時年齢階級別, 主要死因別 死亡構成割合
女 $0.1,50$ 才代男 1.5 ，女 $0.3 ， 60$ 才代男 4.8 ，女 $1.8,70$ 才以上男 14.3 , 女 8.4 であった。このうち虚血性心疾患

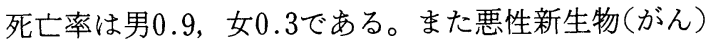

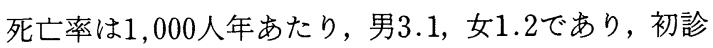
時年令階級別死亡率は 29 才以下男 0 , 女 0,30 才代男 0.6 , 女 $0.1,40$ 才代男 1.4 , 女 $0.6,50$ 才代男 3.5 , 女 1.7 , 60 才代男 4.9 , 女 $3.1,70$ 才以上男 13.7 , 女 6.3 であった。 このうち胃がん死亡率は 1,000 人年あたり男 1.3 ,女 0.4

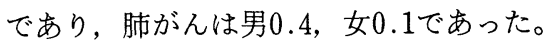

いずれの死因群も29才以下を除いて死亡率は男が女 より高率である。死因別に比較すると, 脳出血のみ, 男より女で高率であるほかはすべて男が高率であっ た。

$$
\text { 4. 考察 }
$$

成人病の早期発見・早期治療を目的とした健康診断 活動は, 昭和58年から老人保健法の施行によって, 40 才以上の全国民に対して健康診断の機会が与えられ， 行政的にも一応の対策がとられることとなったが，健
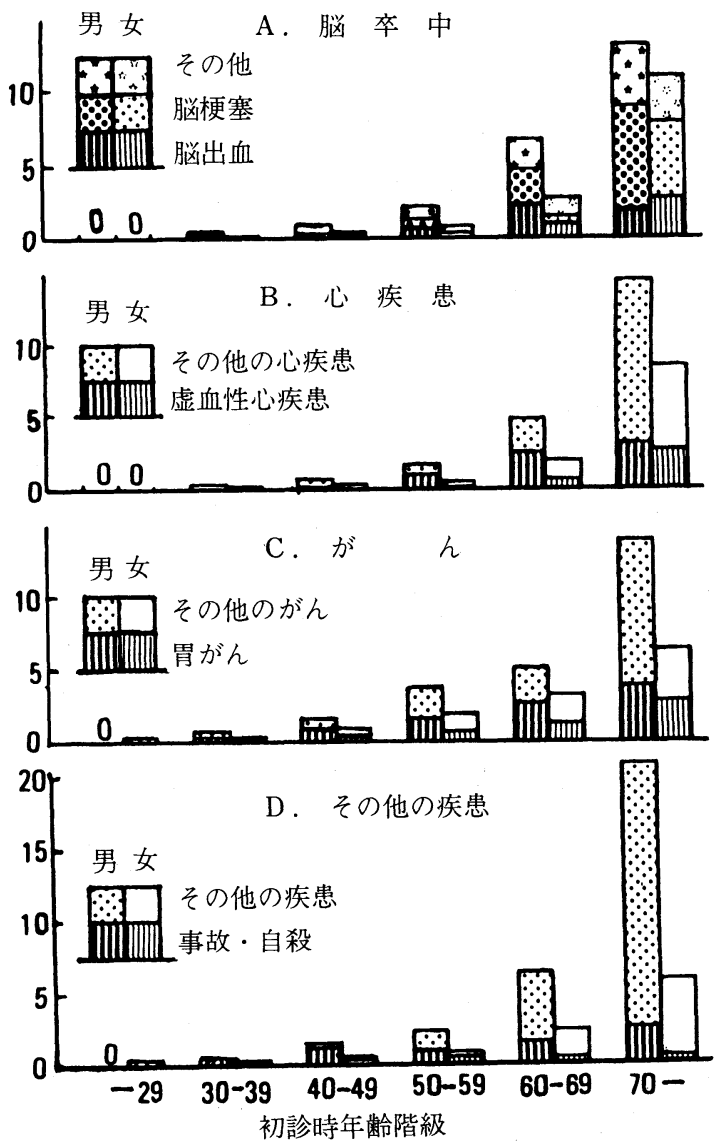

図 2. 初診時年歯階級別 1,000 人年対死亡率 
康診断の内容や，スクリーニングの方法打よびこれら の意義については十分に検討されたとはいえない。

われわれは昭和 46 年以来農村地域住民の健康管理活 動を行なってきて拐り，その効果について現在検討中 である。まず最初に, 成人病健康診断受診者の経過観 察を行ない, 受診後の死亡状況を検討した。

わが国に打ける成人病死亡の動向をみると，昭和 56 年以降，それまで 30 年間死因別死亡の第 1 位を占めて いた脳卒中をぬいて，悪性新生物による死亡が首位と なり，現在総死亡の $24 \% を$ 占めており，次いで脳卒中 $21 \%$ ，心疾患 $18 \%$ となっている。40才から64才の中年 期の死亡はこの傾向がもっとも顕著で, 悪性新生物死 亡は全死亡の約 $1 / 3$, 脳卒中は約 $1 / 5$ を占めている。

ところで石川県は, 標準化死亡比 (SMR: 1964-1973）でみると全国值に比べ脳卒中（96.8）が 低率で, 悪性新生物 (101.9), 心疾患 (108.9) が高率 な県 ${ }^{12)}$ で, 昭和 55 年より悪性新生物死亡が死因別死亡 の首位を占めている。

本研究では, 昭和 46 年から53年までの健康診断受診 者 28,645 人の昭和 55 年末むでの死亡者は 876 人であり, 死因別死亡割合は悪性新生物が $32 \%$ とっとも多く, 次いで脳卒中の $24 \%$, 心疾患 $17 \%$, 事故 $6 \%$, 肺炎 $4 \%$ の順であった。1,000人年あたりの死亡率は全体で 5.2 (男 11.8 , 女 3.3 )であり, 個々には悪性新生物 1.7 (男 3.1 , 女 1.2 ), 脳卒中 1.2 (男 2.8 , 女 0.7 ), 心疾患 0.9 (男 2.3 , 女 0.5$)$, 事故 0.3 , 肺炎 0.2 である。

成人病の総死亡や各死因別死亡には大きな地域格差 が全国的にも，また地方レベルでも認められている。 本研究でも, 市・郡別や能登, 加賀の 2 地域に分けて 死亡率の検討を行なったところ，郡部や能登地方に死 亡率が高率であった。

このような死亡率の地域格差が生じた原因を様々な 角度から究明し, 成人病発生や死亡の要因を明らかに しょうとする研究が進められて拉り，われわれも石川 県に扣いて循環器疾患や悪性新生物の標準化死亡比々 社会経済要因との関連を市町村別に比較検討を行なっ

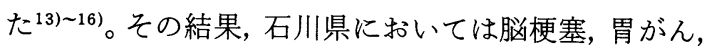
肺がん, 結腸がんなどは都市的背景要因と関連性が強 く, 逆に脳出血, クモ膜下出血, 肺がん, リンパ腫な どは農村的背景要因と関連が示唆された。この結果は 従来の報告5)12) とは多少異なる点もみられ(脳梗塞, 胃 がん), その原因として市町村別の人口差が攪乱因子と なっていることも考えられたので, 北陸 3 県の人口 1 万から 9 万までの市町を対象に再検討を行なったが, ほぼ同様の結果が得られ ${ }^{17)}$, 北陸地方に打ける特性を 示しているものと考吕られた。
また，成人病の総死亡や各死因別死亡には，職業あ るいは社会階層により格差を呈することも知られてい る。英国統計局では社会階層を I (専門職), II (中間 職), III (熟練職), IV (半熟練職), $\mathrm{V}$ (非熟練職) に 分類して括り, 社会経済的地位の低下につれて, 総死 亡, 脳卒中, 虚血性心疾患, 胃がん, 肺がんなどの死 亡率の増加が報告されている18)。ちなみに英国では農 民は社会階層IIに属している。

わが国に招いても，職業別（大分類）に死亡率をみ ると ${ }^{19)}$, 農林漁業作業者は(訂正死亡率男人口10万対), 悪性新生物 117.6 , 脳卒中 77.1 , 心疾患 65.0 と, 3 疾患 で全死亡の $67 \%$ 占めて抢り，とくに脳卒中，心疾患 を他の職種と比較してみると, 採掘作業者, サービス 職に次いで高死亡率となっている。また農民と漁民と 分けて比較してみると年), 農民に脳卒中死亡率が有意 に高くなっている。

本研究では, 農村地域住民の成人病健康診断後の死 亡状況を調査し，死因別検討を行なったが，1人平均 観察年数が 5.8 年と比較的短かいので,さらに観察期間 を延長し，再調査を行なっている。また今回は死亡だ けを問題にしたが, 疾病の頻度を問題にする時には, 病気の発症, 回復, 死亡といら一連の経過を正確にと ら劣る必要があり ${ }^{21)}$, 本研究のような同一集団の長期 追跡が有効であると考学られるので，この面からの再 検討も予定している。

成人病の発生, 死亡の予測に, どのような因子が重 要であるかを疫学的に追求するためには, 一定の集団 について，定められた基準に基づいて調査を行ない, 長期間追跡して発生 (死亡) 者の様々な生活環境, 諸 検査成績を対照者々詳細に比較検討することが必要で ある。わが国でも, 久山町に拈ける population study ${ }^{22)}$ や契煙と主要死亡率との関係をみるための全国調査 ${ }^{10)}$ などの追跡調査が行なわれているが，一般には多大な 時間と労力を要するために行ないにくい。われわれは 本研究で得られた各成人病死亡者を対象に, 生活習慣, 食生活，健康診断諸成績などについて，対照生存者と 比較し各死因に関するリスクファクタ一の解析を行 なって括り，次回報告を行なら予定である。

\section{5.まと め}

昭和 46 年から 53 年すでに成人病総合健康診断を受診 した農村地域住民延 36,008 人の受診票をレコードリン ケージした実受診者 28,643 人(男 6,872 人, 女 21,771 人)

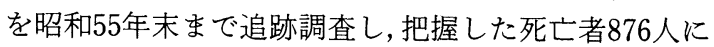
ついて死因調査を行ない，次の結果を得た。

1) 総死亡者は調査対象者数の約 $3 \%$ を占め, 男の 
死亡割合は女の 3 倍に達している。年令階級別死亡割 合は, 男女とも年令が高くなるにつれて増加して抢り, 29才以下を除いて女より男の死亡割合が有意に高率で あった。

2 ) 死因別死亡構成割合は, 循環器疾患 $42 \%$, 悪性 新生物 $32 \%$, その他 $26 \%$ となって抢り, 男で循環器疾 患死亡が多く, 女で悪性新生物死亡が多い傾向がみら れた。

3) 1,000 人年あたりの死亡率は 5.2 (男 11.8 ,女 3.3 ) であり, 主要死因群別では悪性新生物 1,000 人年対 1.7 (男 3.1 , 女 1.2 ) 脳卒中同 1.2 (男 2.8 , 女 0.7 ), 心 疾患同 0.9 (男 2.3 , 女 0.5 ), 事故同 0.3 , 肺炎同 $0.2 て ゙$ あった。主要死因別死亡率は29才以下と70才以上の脳 出血を除きすべて男が女より高率であった。

な拈本研究の一部は文部省科学研究補助金 (課題番号一般研究 C. 56570234)によった。本研究の要旨は第42回日本公鼻衛生学会 総会（昭和58年）にて発表した。

\section{文献}

1)メディカルトリビュン編：日本人の循環器疾患とリスク ファクター, メディカルトリビューン日本支社, 東京, 1982 .

2 ) 小町喜男: 脳卒中の成因をめぐって, 疫学調查の問題点, 日 本臨床, $34: 18-24,1976$.

3 ）佐々木直亮: 食塩と高血圧, 健康管理, $310: 2-15,1980$.

4) 柳川洋, ほか：循環器疾患死亡率の地域格差と食品摂取に関 する統計的検討, 日本公衛誌, $23: 711-719,1976$.

5 ）瀬木三男：食物とがん死亡の国際的観察，がん・日本と世界 （癌の臨床, 別集) 133-141, 篠原出版, 東京, 1980.

6 ) 佐藤徳郎, 注か：胃癌の原因の研究 ( 5 ), 国立公衆衛生院研 究報告, $14: 22-28,1965$.

7 ) 宾戸昌夫, ほか：神奈川県下に扔ける胃がんの疫学的研究,
日本公衛誌, $12: 487-493,1965$.

8 ) 平山雄 : 胃がんの疫学, 特に食習慣の意義に関する研究, 厚 生の指標, 8 (業績集), 18-38, 1961.

9 ) Doll R. \& Hill A B. : Mortality in relation to smoking, 20 years observation on male British doctors, Brit. Med. J. $2: 1525-1536,1976$.

10）平山雄, 浜野芳子：喫煙と主要死因別死亡率との関係, 厚生 の指標, 28(4): 3-18, 1981.

11）野々瀬宣夫：䝟煙之肺癌, 公衆衛生, $43 ： 782-785,1979$.

12) 疾病の疫学分布研究班編：全国市町村別主要疾患死亡率の 分布図, 全死因, がん・循環器疾患・糖尿病・肝硬変・結核, 健康づくり振興財団 (東京), 1981.

13）中川秀昭, ほか：石川県41市町村における循環器疾患死亡率 の地域格差と社会経済要因との関連, 金沢医大誌, 6 ： 85-92, 1981.

14）河野俊一，ほか：石川県下41市町村におけるがん死亡率と社 会経済要因との関連, 北陸公衛誌, 8：37-45, 1981.

15) 河野俊一, ほか: 石川県に打ける循環器疾患の疫学的研究, 昭和56 58年度科学研究費補助金 (一般研究 C) 研究成果報 告書, 1984 .

16）河野俊一, ほか：石川県に打ける悪性新生物の疫学的調査報 告書 (II), 昭和 58 年度がん総合対策調查研究事業報告書, 石 川県対がん協会, 1984 .

17）奥村義治, ほか：北陸三県62市町村におけるがん死亡率と社 会経済的要因との関連, 北陸公衛誌, $10 ： 48-57,1983$.

18）山本俊一：疫学, 161-166, 文光堂 (東京), 1983.

19）厚生省大臣官房統計調查部編：職業-産業別人口動態統計, 厚生統計協会 (東京), 1983 .

20）鏡森定信，ほか：日・英の農民と漁民に拈ける脳卒中および 虚血性心疾患死亡の格差に関する研究, 民族衛生 (印刷中).

21）比嘉恵子, 飯淵康雄 : 疫学的アプローチの再検討, 新井宏明 編, 脳卒中・心臓病の計量疫学, 204-207, 篠原出版 (東京) 1983.

22) 勝木司馬之助, 広田安夫：脳卒中（医学シンポジゥム第21 集), 43-77, 診断と治療社 (東京) 1967. 


\title{
An Epidemiological Study on Adult Diseases among Japanese Rural Inhabitants - Mortality of Inhabitants after Mass Health Screening-
}

\author{
Hideaki NAKAGAWA*, Shunichi KAWANO*, Yoshiharu OKUMURA*, \\ Kenichiro TSUJIKAWA*, Sadanobu KAGAMIMORI ${ }^{2 *}$
}

A follow-up study was conducted until the end of 1980 on 28,643 rural inhabitants who had undergone mass health screening between 1971 and 1978. For those who died, the causes of death were confirmed by death certificates.

The results obtained were as follows:

1) During the observation period, there were 876 death (about $3 \%$ of participants). The mortality was three times greater for males than for females and increased with age. These differences between sexes were statistically significant except the group of 29years old or under.

2) Forty-two percent of the total deaths were for cerebro-cardiovascular diseases, $32 \%$ for malignant neoplasms and $26 \%$ for others. For males, the mortality of cerebro-cardiovascular diseases was greater than those of other causes of death. On the other hand, the mortality of malignant neoplasms was higher among females.

3) The mortality rate per 1,000 person-years of observation was 5.2 (11.8 for males and 3.2 for females). Cause- specific mortality rates were 1.7 per 1,000 person-years for malignant neoplasms ( 3 . 1 for males and 1.2 for females); 1.2 for cerebrovascular diseases ( 2.8 for males and 0.7 for females), 0.9 for cardiovascular diseases ( 2.3 for males and 0.5 for females), 0.3 for accidents and 0.2 for pneumonia. The mortality rates of each aged-group according major causes of death were higher among males than among females except two groups of 29 years old or under and 70 years old or over of cerebral bleeding.

* Department of Public Health, Kanazawa Medical University

${ }^{2 *}$ Department of Community Medicine, Faculty of Medicine, Toyama Medical and Pharmaceutical University 